\title{
Who owns the flows? Distinguishing ownership of resource flows from ownership of resource stocks clarifies debates about property bundles, commons tragedies, and degrowth
}

\author{
Tilman Hartley ${ }^{1}$ \\ University of Bristol, UK
}

\begin{abstract}
Theories of ownership have long focussed on the institutions governing resource stocks such as land, and largely neglected the ownership of resource flows such as the crops that flow from that land. Originating among early modern legal scholars, the assumption that the paradigm form of ownership was of land has been inherited by later theorists. The 'tragedy of the commons' thesis, for example, conflates the absence of stock ownership with the absence of flow ownership, and several commons scholars have now started to move away from a stockcentric conception of ownership. The same assumption has also been inherited by theorists applying Heinsohn and Steiger's 'property economics' to theories of degrowth. Here, I recast their theory to include ownership of flows as well as stocks, answering critics who point out that their theory cannot account for unsecured debts. This recasting places greater focus on the different ways in which ownership institutions not only assign an owner to a resource, but also motivate the transfer of resources between individuals. This prompts a new way to frame a key question for theorists of degrowth: in a nongrowing economy where fewer transfers can be motivated by the likelihood of receiving returns on loans, will this result in more possessive behaviours, in more communal ownership norms of reciprocity, or in more command ownership through coercion and status? Existing theory, focussed on stocks, groups these different institutions together as 'private' or 'nonproperty' ownership. This article suggests that disambiguation of the different 'nonproperty' institutions that govern the ownership and transfer of resource flows is key to better understanding the political and institutional implications of degrowth.
\end{abstract}

Key words: Property, possession, degrowth, institutions, commons, private property, social metabolism

\section{Résumé}

Depuis longtemps, les théories de la possession ont été centrées sur les institutions régissant les stocks de ressources telles que la terre, et ont largement négligé la possession des flux de ressources tels que les récoltes qui en découlent. D'origine parmi les premiers juristes modernes, la supposition que le paradigme de la possession était la possession de la terre a été héritée par les théoriciens qui ont suivi. La thèse de la "tragédie des biens communs», par exemple, confond l'absence de la possession des stocks avec l'absence de possession des flux, et maintenant plusieurs chercheurs des biens communs ont commencé à s'éloigner d'une conception stock-centrique de la possession. La même supposition a également été héritée par des théoriciens appliquant «l'economie de la propriété» de Heinsohn et Steiger aux théories de la décroissance. Ici, je reformule leur théorie pour inclure la propriété des flux ainsi que des stocks, en répondant aux critiques qui font remarquer que leur théorie ne peut pas prendre en compte les dettes non garanties. Cette reformulation met davantage l'accent sur les différentes manières dont les institutions de possession attribuent non seulement un possesseur à une ressource, mais motivent également le transfert de ressources entre individus. Ceci suggère une nouvelle façon de poser une question clé pour les théoriciens de la décroissance: dans une économie qui ne croît pas, où moins de transferts peuvent être motivés par la probabilité de recevoir des rendements sur des prêts, cela entraînera-til des comportements plus possessifs, des normes de réciprocité relatives à la possession communale, ou plus de possession de commande par la coercition et le statut? La théorie actuelle, axée sur les stocks, regroupe ces différentes institutions en tant que «privés» ou «non propriétaires». Cet article suggère que la désambiguïsation des différentes institutions de «non-propriété» qui régissent la possession et le transfert des flux de ressources est essentielle pour mieux comprendre les implications politiques et institutionnelles de la décroissance.

1 Dr. Tilman Hartley, School of Sociology, Politics and International Studies, University of Bristol, UK. Email: tilmanhartley "at" protonmail.com. Earlier versions of this article benefited from comments by Magnus Feldmann, Marina Fischer-Kowalski, Mario Giampietro, Jutta Weldes, and two anonymous reviewers. 
Mots-clés: Propriété, possession, décroissance, institutions, biens communs, propriété privée, métabolisme social

\section{Resumen}

Las teorías sobre la posesión se han centrado durante mucho tiempo en las instituciones que gobiernan las recursos stock, como la tierra, y han descuidado en gran medida la posesión de los flujos de recursos, como la cosecha que fluye de esa tierra. Originada entre los primeros eruditos legales modernos, la suposición de que la forma paradigmática de posesión era de la tierra ha sido heredada por teóricos posteriores. La tesis de la 'tragedia de los bienes comunes', por ejemplo, confund la ausencia de posesión de stocks con la ausencia de posesión de flujo, y ahora varios investigadores de los bienes comune han comenzado a alejarse de una concepción de posesión centrada en stocks. La misma suposición también ha sido heredada por los teóricos que aplican la "economía de la propiedad" de Heinsohn y Steiger a las teorías del decrecimiento. Aquí, reformulo su teoría para incluir la propiedad de los flujos así como las stocks, respondiendo a los críticos que señalan que su teoría no puede explicar las préstamos no aseguradas. Esta reformulación pone mayor énfasis en las diferentes maneras en que las instituciones de posesión no solo asignan un propietario a un recurso, sino que también motivan la transferencia de recursos entre individuos. Esto genera una nueva forma de formular una pregunta clave para los teóricos del decrecimiento: en una economía que no está en crecimiento, donde menos transferencias pueden ser motivadas por la probabilidad de recibir rendimientos de los préstamos, ¿esto resultará en comportamientos más posesivos, en normas de propiedad más comunitarias de reciprocidad, o más propiedad del mando a través de la compulción y el status? La teoría actual, centrada en las acciones, agrupa a estas diferentes instituciones como propiedad 'privada' o 'no propiedad'. Este artículo sugiere que la desambiguación de las diferentes instituciones 'no privadas' que gobiernan la posesión y la transferencia de flujos de recursos es clave para comprender mejor las implicaciones políticas e institucionales del decrecimiento.

Palabras clave: Propiedad, posesión, decrecimiento, instituciones, bienes comunes, propiedad privada, metabolismo social

\section{Introduction}

Ownership institutions are a fundamental link between the social and natural worlds and have long been central to the study of the ecological correlates of economic, social, and political processes. In recent years, the debates around degrowth have prompted consideration of the ways in which property institutions drive growth, and the role that changes to ownership may play in degrowth (Alexander 2011; Gerber and Steppacher 2017; Steppacher and van Griethuysen 2008; van Griethuysen 2012). Jonathan DeVore has most recently suggested that these degrowth debates may benefit from drawing together insights from many different frameworks of ownership, arguing that "degrowth conversations, and progressive politics more broadly, can draw on these different frameworks to circumvent old antinomies", antinomies which have long tended to dichotomize between private ownership and other ownership forms (DeVore 2017: 647).

In this article, I suggest that a potentially powerful framework for integrating different approaches is to analyse different ownership institutions in terms of the types of resources that they govern. In this, I draw on recent work that makes a distinction between 'fund' resources that provide 'services', and 'stock' resources that output resource 'flows' (Daly and Farley 2011: 71-73; Farley 2012: 45-50, building upon Georgescu-Roegen 1971). I argue, in particular, that existing frameworks have tended to take the ownership of resource stocks such as land as the paradigmatic form of ownership, and that this has resulted in neglect of the institutions that govern resource flows, such as the harvest that flows from that land. The textbook economic terminology, for example, categorizes ownership institutions in terms of rivalry and excludability, according to which most resource flows are identified as rival and excludable and so classified as 'private' (see Table 1; McKean 2000; Ostrom 2005; building upon Samuelson 1954). But such a classification obscures the fundamental differences between individuals retaining the flows that they obtain, or transferring resources according to communal, command, or property ownership institutions that govern the transfer of those flows to others in the community, to those of higher status, or to those with legal title to those resources. 


\begin{tabular}{|l|l|l|}
\hline & Excludable & Non-excludable \\
\hline Rival & Private & Common \\
\hline Nonrival & Club & Public \\
\hline
\end{tabular}

Table 1: Two-by-two table categorising resource ownership institutions by binaries of excludability and rivalry. Resources are rival if one person's use leaves less in quality or quantity for another person, and so are sometimes called subtractive resources (Farley 2012: 47-49). Excludability is often represented as a binary, but has recently been argued to be more of a continuum depending either on how easy it is to exclude people or how many people are actually excluded (Daly and Farley 2011: 73; McKean 2000: 30, 36; Ostrom 2005).

I begin in the next section by setting out the distinction between funds, services, stocks, and flows. In Section 3 I outline the history of the debate among legal scholars about whether property can be conceived as a 'bundle of rights', and suggest that this 'bundling' approach still tends to attempt to reduce all forms of ownership to ownership of resource stocks, particularly land, and so still relatively neglects the ownership of resource flows. In Section 4, I suggest that theories of resource depletion inherited the assumption that land ownership is the paradigm form of ownership, and so similarly long neglected the institutions governing resource flows. By way of illustrative example, I discuss how Garrett Hardin's (1968) well-known 'tragedy of the commons' thesis mistakes the absence of rights to a stock of land for the absence of rights governing resource flows from it. I then note that the recent shift of some commons scholars, particularly those of the Bloomington School, towards a focus on individual actions implies a shift in their level of analysis away from collective ownership of stocks and towards a greater focus on individual entitlements to flows. Similarly, in Section 5, I suggest that Gunnar Heinsohn and Otto Steiger's 'property premium' theory of interest, recently powerfully integrated into the degrowth debate (Steppacher and van Griethuysen 2008; van Griethuysen 2012), similarly takes resource stocks as the paradigm form of ownership in an attempt to justify interest payments in terms of the recompense for no longer being able to burden or collateralize a resource stock - again, typically, land. However, this theory has been criticized for being unable to account for loans that do not seem to be the result of burdening or collateralizing resources. Extending the property premium theory to include ownership of resource flows answers this critique and suggests that payment of interest motivates lenders to transfer their resources simply on the expectation of receiving more resources in return, whether or not the debtor has stock to collateralize. In section 6 I outline the implications of this analysis for the degrowth debate.

\section{Funds, services, stocks, and flows}

Different resources have different characteristics. A fundamental distinction has been made by ecological economists between stock resources that output flows physically transformed by their use, and fund resources which provide services that are used without their physical consumption (Daly and Farley 2011: 7173; Farley 2012: 45-50; Georgescu-Roegen 1971). Funds are a specific configuration of resources; a car, for instance, is a specific configuration of glass, metal, plastic, and rubber. Funds generate services at a given rate over time, and services cannot be stockpiled: a car that is not driven one day cannot be used twice as intensely the next. Though they may be worn out a little, funds remain largely physically untransformed by their use, and there is a limit to the rate at which they can be used; a car, for example, cannot be used to carry more people than it can physically contain. Funds may be costly to provide initially, but since they are not transformed by their use, they can provide benefits to many different people.

Stocks output flow resources that are physically transformed by their use, for example when a tree is transformed into ash, heat, and smoke by combustion. Because they are physically transformed by their use, both stocks and the flows that they output are used up in the act of production; in economic jargon, they are said to be subtractable and depletable. The rate at which stocks output flows is not determined by their physical characteristics: a forest can be cut down very quickly, or can be harvested at a very slow rate. Analogous to the 
relationship between capital and income, a resource stock can output resource flows but if the flow is at too high a rate for the stock to be replenished then it will be depleted. Of course, a thing that can be used as a stock may also have aspects that can be used as a fund: a stock such as a lake may provide the opportunity for swimming as well as a flow of drinking water from it. Similarly, a fund can be converted into a stock resource if it is used, not for the services provided by its configuration, but by transforming the physical materials that the resource provides, for example when the material from a car is reused in a scrap yard, with the rubber and plastic even burnable as fuel (Daly and Farley 2011: 71-73; Farley 2012: 45-50). Importantly, whilst stocks output resource flows, flows themselves do not have any outputs. So no matter how large a quantity of resource flow such as meat or bread, it does not constitute a resource stock since it is not capable of producing further resource flows, whereas a pasture of grazing animals or a field of wheat does constitute a stock resource since it produces a flow of outputs. ${ }^{2}$

The standard economic terminology for categorising ownership institutions builds on the theory of public goods developed by Paul Samuelson (1954), and categorizes physical resources in terms of rivalry and excludability. According to the two-by-two table produced by these categories (see Table 1), resource flows are typically privately owned since their use is inherently rival and everyone except the user is excluded. This is perhaps most obvious in the case of resources used for their energy: when somebody eats an apple, nobody else can eat it and everybody is forever prevented from eating it ever again. But to simply classify resource flows as 'privately owned' obscures the fundamentally different kinds of rules that actually govern who is entitled to use such resource flows. Four kinds of rules governing resource flows are readily identifiable. The first of these, first possession ${ }^{3}$ is where resource flows are retained by their possessor; under communal ownership each community member is entitled to acquire flows from others in the group; under command ownership resources flow to those of higher status; and under property ownership flows are transferred to whomever holds a legal title to them. To merely classify these very different ownership institutions as 'private ownership' obscures these fundamental differences between them.

The purpose of this article is to highlight the causes and consequences of neglect for institutions governing ownership of resource flows. But before progressing to that discussion, it is important to state that funds and the services derived from them may also become owned. For example, a car may have an owner who is able to exclude others from travelling in that car if they so choose. Though a more thorough analysis of ownership institutions governing funds and services is beyond the aims of this article, it is important to note that since the flow output from stocks is not limited in the way that the service output from funds are fixed at a particular rate, and since in many cases it has proved difficult or impossible to create institutions to exclude others from certain services, owners of funds often have an incentive to convert funds into stocks, extracting flows from those stocks and thereby increasing their income in the short term. For example, a forest acts as a fund providing ecosystem services such as water purification and climate regulation from which it is very hard to exclude others, but it can fairly rapidly be converted into a resource stock by clear cutting and the material flows from it sold (Farley 2012: 46, Gerber and Scheidel 2018: 191 n10). So, whilst the ownership institutions governing resource flows have, as I suggest below, been relatively neglected due largely to oversight, the

\footnotetext{
2 In quantitative socio-metabolic modelling, the classification of resources depends upon the scale and perspective adopted, and differs between models, with the classification of resources in both MEFA and MuSIASEM differing slightly from the definitions given here. Usefully, however, across frameworks it is intuitive to characterize flows as elements that appear or disappear over the duration represented by a model. For example, in the short term, an individual sheep may output flows of milk and wool, but over a much longer time period the sheep itself would be modelled as an item of flow produced by wider biophysical systems (see Gerber and Scheidel 2018; Giampietro et al. 2009).

3 My use of the term 'first possession' here is consistent with others across various disciplines (for example Libecap 2007; Lueck 1995, 1998; Kanngiesser et al. 2015; Rose 1985) and should not be confused with Heinsohn and Steiger's usage of the term 'possession' to mean 'nonproperty', which for them also includes communal and command ownership institutions. For terminological clarity, Heinsohn and Steiger differentiate 'property' from 'possession' on the basis that only property creates legally transferable titles and so establishes the foundation of their theory of interest, which I discuss and extend below. This usage differs from elsewhere in the literature, which sometimes differentiates between 'possession' as the physical control of resources and 'property rights' as social rules defining a set of rights and obligations (see also van Griethuysen 2012: $263 \mathrm{n}$ 2). As a final point, though others eschew the term (Hoffman 2013), I have found it useful to use 'ownership' as a more general term to include both 'property' and 'possession'.
} 
neglect of ownership of funds and of services may also partly be due to the difficulty often involved in constructing ownership institutions to govern them - as well, perhaps, as the incentive that owners have in considering the resources they own to be stocks, rather than funds. In this connection, Julien-François Gerber and Arnim Scheidel have recently identified stocks, flows, funds, and services as the four distinct analytical categories of resource used in socio-metabolic modelling, arguing that "[s]ubstantive ecological economics requires an understanding of the relationships between all of them" and urging the integration of politicalinstitutional structures into existing socio-metabolic frameworks (2018: 190). Similarly, in her study of biomass distribution in the Tana Delta in Kenya, Leah Temper (2016) notes that existing material flow analyses do not yet integrate analysis of the way that resources flow through an economy. Future research into the relationships between the ownership institutions that govern different resource types may well prove a promising means to achieve such an integration, perhaps providing a basis for a more fully political ecological economics as advocated by scholars such as R. Michael M'Gonigle (1999) and Temper (2016).

\section{Bundles of rights}

Ownership of resource stocks, particularly land, has long been taken to be the paradigm form of ownership. Dating from the Middle Ages the most usual and simplest form of ownership in the English legal system had been that of fee simple absolute, whereby the king or queen granted an owner dominion over some piece of land as a kind of delegated sovereignty. Then, the word 'property' referred to some thing, typically land but sometimes some other form of tangible object, owned by an individual (Klein and Robinson 2011: 193194). This view of ownership has been described in many ways (Honoré 1961: 107, 147; Katz 2008: 275, 281; Klein and Robinson 2011: 194; Singer 2008; Underkuffler 2003: 12), often with reference to the famous description by eighteenth century legal scholar William Blackstone of property as "the sole and despotic dominion which one man claims and exercises over the external things of this world, in total exclusion of the rights of any other in the universe" - though those who quote him sometimes omit to mention that Blackstone immediately goes on to discuss the qualifications and limitations of such an absolute conception of ownership (Blackstone 1765-1769: 2.1; Rose 1998).

Indeed, by the end of the nineteenth century, the idea that ownership could be conceived of as absolute 'dominion' began to be ever more criticized. In its place, the notion that ownership should instead be better understood as a 'bundle of rights' became popular amongst scholars following the English common law tradition, with this 'bundle' a metaphor for the multiple rights specifying what the owner of a thing was allowed to do with it. This change in the understanding of the concept was provoked by the practical problem that the 'dominion' conception of ownership was not very useful for explaining how numerous different people could have rights to a single piece of land. In reality, rather than a piece of land being used only by a single owner, in many cases all or part of the land could be leased for a certain length of time, whilst licences could grant access only to certain parts of it, and many other varied permissions and easements could give other people one or more rights to it. This was troublesome for the 'dominion' view of ownership, but ownership conceived as a 'bundle of rights' allowed a much clearer explanation of how such rights could be unbundled and how different rights to the same object could be held by different people (Klein and Robinson 2011). There were also other benefits of the view that ownership could be conceived as a 'bundle of rights', with one early and influential contributor, Wesley Newcomb Hohfeld, making much of the distinction between in rem rights held by a person with respect to a thing and in personam rights held by a person with respect to another person (Hohfeld 1913: 16; 1917: 710). With ownership no longer conceived as being the absolute ownership by an individual of a thing but as a 'bundle of rights' held by various different people, Hohfeld argued that it made sense to view ownership as rights held with respect to other people, and not as the relation between a person and an object. Nevertheless, the underlying assumption that the paradigm case of ownership is real estate has remained strong. Indeed, underlying the 'bundle of rights' view there remains a conception that ownership of resource stocks such as land is the paradigm case of ownership, with the 'bundle' defined in terms of the different rights that individuals have to that stock. As Carol Rose puts it, for modern legal scholars, "'property unmodified' still means land" (Rose 1998: 614). 
Around the end of the twentieth century, however, some theorists began to express dissatisfaction with the 'bundle of rights' view on the grounds that it turned ownership into a set of possible social relations, and so failed to distinguish ownership from any other kinds of rights. Scholars such as James Penner (1997), Richard Pipes (1999), and Larissa Katz (2008) made various attempts to resurrect the notion of ownership rights in terms of in rem rights held over an object. An earlier argument by Robert Ellickson had suggested that any position which took ownership to be an in rem right over an object could easily be translated into a set of in personam rights with regard to other people (Ellickson 1991: 115; 1993: 1315, 1362-1363). In this manner, in rem rights began to be interpreted as rights "against the world" in which by default the rights granted by ownership were considered to amount to a complete bundle of rights which prevent everyone other than the owner from doing anything whatsoever with that thing. An alternative to the attempts at resuscitating the in rem view was the approach proposed by scholars such as Carol Rose (1994, 1998) and Gregory Alexander (1997), who argued that these problems could be remedied by amalgamating the two opposing views into a position whereby ownership is seen as a relation both between people and with respect to things; that this approach became the orthodoxy is nicely illustrated by the fact that the American Law Institute came to define 'property' as "legal relations between persons with respect to ... things" (quoted in Underkuffler 2003: 12). In support of this approach, Gregory Alexander found that very few theorists had ever actually held solely in personam or in rem views, as most found it necessary to include both relations between people and relations between owners and objects in their accounts (Alexander 1997). Similarly, John Meyer recently noted that the attempts by legal theorist Thomas Grey and environmental philosopher Gary Varner to articulate a non-absolute conception of ownership were hampered by their historically inaccurate assumption that things had, once, been owned absolutely (Meyer 2009: 112-116).

However, whilst arguably applying to resource stocks like land, the conclusion that nothing has ever been owned absolutely certainly does not apply to resource flows which are transformed or even consumed by the person using them. After all, when the use of an object by its owner entails its destruction, the exercize by an owner of their right to use such a resource really does represent a Blackstonian right 'over the external things of this world, in total exclusion of the rights of any other in the universe'. When somebody eats an apple or a fish, or burns a piece of wood or lump of coal, then every other person is forever prevented from ever making any use of that thing ever again. Though proponents of the 'bundle' view have typically tended to interpret these 'bundles' as a collection of all the different rights that may be held in relation to the assumed paradigm ownership of some stock of land, both Alexander (2011: 85-90) and DeVore (2017: 647) have suggested that the 'bundle' view can help motivate a move away from the tendency to conceive of ownership in absolutist and dichotomous ways. I suggest here that a more clearly articulated theory of ownership - particularly one differentiating ownership of resource flows from stocks - may provide a clearer framework for the analysis of both the causes of resource overuse and the institutional implications of degrowth than the existing stock-centric approaches.

\section{Overuse tragedies}

Commons scholars initially inherited the assumption that the paradigm form of ownership was of a resource such as land, with commons typically described in terms of the co-ownership of resource stocks. A useful illustration of the kinds of problem that results from neglect of the distinction between stocks and flows is the confusion that surrounds theories of ownership and resource depletion. The most infamous of these, the so-called 'tragedy of the commons' thesis advanced as a general argument by Garrett Hardin in 1968, places private ownership of stocks in sharp distinction with common ownership of stocks, and asserts that common ownership results in the overuse of resources, concluding that the only two ways to prevent overuse are either state or private ownership (Hardin 1968). Despite the article's popularity, it has been widely criticized for lacking clarity over terminology and for being unable to account for the many successful commons found throughout the world; G.N. Appell concisely summarizes the harshest critics by describing the thesis as "conceptually flawed and empirically wrong" (Appell 1993: 5). Hardin himself eventually acknowledged that he had mistitled the phenomenon and that what he had intended to refer to were 'unmanaged commons' (Hardin 1991). Underlying this conceptual mix up, I suggest, is neglect for the difference between the ownership of stocks and of flows, since Hardin assumed that if stocks are unowned then so too would be the resources that flow from them. But as empirical studies have shown, under a commons regime different users might have 
rights to certain resource flows even though it is quite possible nobody asserts any claim to own the resource stock at all (Bromley 1992; Feeney et al. 1990; Hoskins and Stamp 1963; Ostrom 1990). This aspect of ownership in agrarian peasant communities was long ago noted by Nicholas Georgescu-Roegen, who described how the institutions of peasant communities did not govern the land itself, but instead governed the flows of income from the land (Georgescu-Roegen 1965: 209). To borrow Helmut Haberl's phrase, though we may often speak in terms of land ownership, what such commoners typically own is "not land but rather its function for biomass production" (Haberl 2015: 424). If the rights to appropriate the flow from the stock are unregulated then overuse is a likely outcome. Irrespective of the status of the ownership or nonownership of the stock, in reality resource stocks have been maintained without depletion, often for centuries, provided that the ownership of flows is adequately governed (Bromley 1992; Cole and Ostrom 2012; Feeney et al. 1990; Hoskins and Stamp 1963; Ostrom 1990).

Nevertheless, commons scholars have long engaged in analysis in terms of collective ownership of resource stocks. For example, some still refer to Ciriacy-Wantrup and Bishop's classic definition of common property as the "distribution of property rights in resources in which a number of owners are co-equal in their rights to use the resource" (Ciriacy-Wantrup and Bishop 1975: 714, cited in Calvo-Mendieta et al. 2017; emphasis in the original), and though others have begun to theorize ownership of commons in terms of the actions that individual commoners may take, ${ }^{4}$ their framework remains implicitly couched in terms of the rights (McGinnis 2011; Ostrom 2005, 2011) or the abilities (Ribot and Peluso 2003) that individuals have to perform actions regarding a resource stock. But if using a resource flow may entail its destruction, effectively excluding all others from it forever, then ownership of flows would seem to be a paradigm case of ownership. Yet having inherited stock-centric assumptions, theorists have instead gone to considerable lengths to construe such actions in terms of fragmented collective ownership of some stock, rather than simply talking about who owns the flows in the first place. It is my suggestion here, then, that it might help clarify our theories of depletion and degrowth, at least, if we were to discuss these issues explicitly in terms of ownership of resource flows.

\section{Property and interest}

Like DeVore, Heinsohn and Steiger similarly suggest that excessive emphasis has been placed on the "traditional dichotomy" between individual and collective ownership (Steiger 2006: 184). They argue that, instead, increased attention should be paid to the more fundamental difference between merely possessing a resource and having a legal property title to that resource. The mere possession of resources, they argue, at most entails the right to physically use those resources, whereas 'property' consists of the creation of legal titles which allow the holder of those titles to burden assets when creating credit and to encumber them as collateral for securing loans (Heinsohn and Steiger 2008, 2013; Steiger 2006). Interest payments, they argue, are compensation for the loss of a proprietor's ability to further burden and collateralize their property. This, they argue, is the answer to "economic theory's key question: what is the loss that must be compensated by interest?" (Heinsohn and Steiger 2008: 184, emphasis in original).

This key question has an intellectual history going back millennia. The Hebrews inherited from the ancient Mesopotamians a distinction between interest on consumption loans which was periodically forgiven and interest on commercial loans which was not (Hudson 2002). This tradition, along with Roman law and the philosophy of Aristotle, influenced the Church's distinction between legitimate 'interest' charged as recompense for losses suffered by lenders making a loan and unlawful 'usury' which represented a charge merely for the use of a thing (Noonan 1957). In the terminology of this article, if a loan is of a fund that is worn out a little by the borrower then the lender can legitimately ask to be paid for the loss they have suffered, but if the loan is of a resource flow which is consumed by use then it can only be repaid by replacing it or by paying the lender something of equivalent value. The logic of the Church, inherited from the early Roman mutuum loan contracts (Storck 2009: 449-450), was that since repayment of an amount that has been borrowed is consideration for precisely the amount that has been borrowed, any payment in excess of that principal can only be justified if it is compensation for some other loss suffered by the lender. In times where money would literally be put into

\footnotetext{
4 Compare to Ronald Coase's suggestion that "We may speak of a person owning land and using it as a factor of production but what the land-owner in fact possesses is the right to carry out a circumscribed list of actions" (Coase 1960: 44).
} 
storage if unused, the division between 'interest' and 'usury' was in principle reasonably clear: had the lender not made the loan then the money would simply have stayed in their store cupboard, so as long as the debtor repaid the principal the lender had not suffered any loss. As early as the thirteenth century, however, an argument was being made that lucrum cessans or 'foregone profits' incurred by a creditor when making a loan should be recompensed by debtors as legitimate interest (Graeber 2011: 440; Munro 2003: 511-512). The eventual ubiquity of money markets ultimately meant that any interest-free loan would imply a loss to the lender, since money was no longer kept in store cupboards but invested, and in the absence of making the loan the lender could always have lent the money elsewhere and earned interest upon it. So a key task for economic theorists became to find some normative justification for the interest charged in those money markets. This is why Heinsohn and Steiger identify economic theory's key question to be 'what is the loss that must be compensated by interest?' Arguing against the neoclassical view that interest is payment for the temporary loss of goods as suggested by neoclassical economists, and against the Keynesian view that it is for the temporary loss of money, Heinsohn and Steiger's argument is that the lender suffers the loss of the 'immaterial yield' from the 'property premium' (Steiger 2006: 184-185), that is, the loss of "the potential to burden assets to create and loan money or to borrow it" (Heinsohn and Steiger 2008: 194).

It is worth noting, since I have yet to find this stated in the literature, that Heinsohn and Steiger's account is a normative theory to justify the charging of interest, to the effect that interest is justifiable up to any rate that the market will bear. Since they argue that interest compensates a proprietor for the loss of their 'property premium' which consists of "the potential to burden assets to create and loan money", the next logical question to ask is: how much is this 'property premium' worth? Since the value of the property premium derives from the ability of the proprietor to create money to lend to others, its value derives from the ability of the proprietor to charge interest on the money they lend. So, if interest is paid to compensate a proprietor for the loss of their ability to create a sum of money, then the precise value of this loss is the interest that they would have been able to charge on loans of that money elsewhere. As such, the normative conclusion of their argument is fairly similar to the conclusion of the 'foregone profit', or lucrum cessans, argument centuries ago: that the precise value of interest that can legitimately be charged to one debtor is exactly equal to the value of interest that could legitimately be charged elsewhere. That is: interest can be charged at whatever rate the market will bear.

Moreover, critics have also raised empirical concerns with Heinsohn and Steiger's account, since in practice loans are often procured without collateral (Lau and Smithin 2002: 9; Strunz et al. 2015: 13). ${ }^{5}$ In an early account, Heinsohn suggests that in the case of uncollateralized loans the debtor's collateral is merely not specified since the "quality of assets belonging to him or her is beyond doubt" (Heinsohn and Steiger 2000: 83), but this argument could not explain the many examples of loans where collateral is totally unspecified, such as completely unsecured loans (Strunz et al. 2015: 13) and lending to businesses that hold negligible assets (Lau and Smithin 2002: 9). Later, both Heinsohn and Steiger acknowledge the existence of unsecured loans, noting their role in financial crises (Heinsohn and Steiger 2008: 217) and citing research from 1992 that 70 per cent of commercial and industrial lending in the US was secured (Steiger 2006: $204 \mathrm{n} 11$ ). Of course, this figure implies that 30 percent of commercial and industrial lending was uncollateralized, to which can be added the many consumer, student, and other personal loans that are all unsecured. Moreover, Heinsohn and Steiger identify subsistence loans as an alternative to the social safety net provided in societies with communal and command ownership institutions (Heinsohn and Steiger 2008: 190-191), yet their assumption that all loans are collateralized somewhat obscures the fact that those without anything to collateralize are those most likely to procure subsistence loans in this way. It may be that Heinsohn and Steiger consider all unsecured loans to be deviant or illegitimate, but this would be a normative claim considerably stronger than their empirical statements that secured loans are "a fundamental necessity" in highly developed economies (Steiger 2006: 204 n11), or that insufficient collateral can lead to higher interest rates (Steiger 2006: $204 \mathrm{n} 13$ ) and financial crises (Heinsohn and Steiger 2008: 217).

\footnotetext{
5 This important point is made by Strunz et al. in their 2015 working paper but not in the 2017 published version discussed below, where their focus is on whether Heinsohn and Steiger have indentified a growth imperative or merely a growth driver.
} 
Consistent with the analysis in this article, I interpret the underlying limitation of Heinsohn and Steiger's account to be that they focus exclusively on the ownership of resource stocks, to the neglect of resource flows. Fundamentally, a creditor is motivated to loan some resource in expectation of receiving a larger value of resources from the debtor in return - as Heinsohn and Steiger have themselves noted (Heinsohn and Steiger 2008: 190-191). Where the debtor can provide some collateral as a guarantee then this may reduce the risk that the debtor will default, but it does not change the fact that what the creditor hopes to acquire is repayment plus interest from the debtor. This explains the many cases where lenders are satisfied that they are likely to receive their expected returns, even in the absence of any pledged collateral. After all, those who own no resource stocks can often still acquire resource flows, whether in exchange for their labor or in the successful realisation of their business plans (Ananya 2010; Haiven 2014; James 2014; Maurizio 2012; Maurer 1999; Ross 2014; Schuster 2014). Fundamentally, the right to future income flows is often precisely the title that is acquired by a creditor in a loan agreement; what matters to a creditor is that they receive the flow of income for which they have contracted. So recasting property ownership to include the entitlement to resource flows rather than solely as titles to some fragment of resource stock serves as a response to the criticism that so many actual loans are unsecured; it also suggests that financial crises might usefully be understood less as the surfeit creation of unsecured money and rather in terms of the overoptimistic expectations of lenders with regard to the future returns they are likely to receive.

The normative problem remains: what is the loss that must be compensated by interest? Despite the attention that has been paid to this key question, a persuasive answer remains elusive. It may, then, be appropriate to leave the search for a normative justification for interest for now, and to approach the issue in a more empirical way. Such empirical enquiry might begin with the question: why do debtors consent to pay interest, despite the fact that it is far from obvious that they receive any consideration in return, nor compensate the lender for any loss? An answer, suggested by Heinsohn and Steiger's work, is that whilst communal and command ownership institutions govern transfers between individuals through reciprocity and custom or status and coercion, under property institutions transfers are motivated by an expected return (Heinsohn and Steiger 2008: 190-191).

That many credit contracts are contracts for the future transfer of resource flows is also consistent with much of the more recent research into the ancient origins of property and interest-bearing loans, and helps us better understand their historic consequences. Whilst not every credit contract is a title to some future resource flows - after all, any good or service contracted for future delivery constitutes a credit relationship - titles to the transfer of future resource flows, neglected when property is cast solely in terms of titles to resource stocks, have been a crucially important institutional development. If the loan were of a resource fund or a resource stock then it might be used by a debtor to produce enough flows or services to pay a creditor their interest; but by definition, loaned resource flows cannot be used to produce further flows. So where a debtor has borrowed resource flows, the interest that they contract to pay must come from resources they acquire elsewhere. Heinsohn strongly argues that markets first arose in ancient Mesopotamia from the settlements of debts between "private proprietors who have no choice but to constitute a market to turn their commodities into the means in which their debts are contracted" (Heinsohn 2008: 249, quoting his 1982 dissertation); but the settlement of debts of nonproprietors remains neglected throughout his analysis. Yet credit was also contracted by nonproprietors in ancient Mesopotamia, with these titles a defining feature of the way in which ancient rulers and, later, private creditors accumulated wealth by offering interest-bearing loans of seeds, animals, and materials to tenant farmers and extracting a fixed rate of return (Garfinkle 2004; Hudson 2000; Hudson 2002: 49). One consequence of these credit contracts for the delivery of resource flows was the emergence of a labor market as early as the late third millennium $\mathrm{BC}$, as wages likely became the only means by which propertyless individuals could pay off their debts (Adams 2006: 160, 164).

In short: debtors consent to pay interest on loans because it is this payment that motivates a lender to lend to them in the first place. Moreover, in the absence of a social safety net they may not have all that much choice. Perhaps some normative explanations can be constructed to justify those interest payments, though the fact remains that creditors and debtors have long engaged in these transfers even in the absence of any post hoc justification by economic theorists. In the end, what matters for an empirical theory of interest is that debtors pay interest because otherwise creditors would not lend to them. 


\section{Consequences for the degrowth debate}

Independently of their normative theory, Heinsohn and Steiger also advance an important argument that the interest that accrues upon loans is a key driver of an increase in economic activity. They write that "The demand for a rate of interest forces upon [the debtor] a value of production, expressed in terms of quantity, time, money or price, which must be greater than the money proper advanced as capital. This demand thus necessitates a value surplus in the production of commodities, the rate of profit" (Heinsohn and Steiger 2000: 94, emphasis in original). Debate continues about whether positive interest rates constitute a growth imperative, with much of this literature now following Hans Christoph Binswanger (2013) in explicitly distinguishing between an unavoidable systemic growth imperative, and a growth impetus or driver which merely incentivizes economic growth (Strunz et al. 2017). To the extent that interest-bearing loans incentivize debtors to return a greater value than they have borrowed, such loans are widely considered to drive growth even if not constituting an imperative, and a review of research into local credit systems found generalized positive interest rates to be incompatible with a postgrowth economy (Gerber 2015). Recent analyses have now placed changes in ownership institutions at the centre of the degrowth debate, both as a means to diffuse the explosive drive for growth attributed to the institution of property, and as a means to minimize the distributional conflicts that may arise in a nongrowing economy (Alexander 2011; Gerber and Gerber 2017; Gerber and Steppacher 2017; Kallis et al. 2015; Steppacher and van Griethuysen 2008; van Griethuysen 2012). In light of the analysis presented above, I end this article by contributing three points to that debate.

The first point, building on Heinsohn and Steiger's argument, is that collective ownership does not necessarily imply the end of a drive towards growth: collectives can become indebted just as individuals can become indebted. Though some have argued that a degrowth transition will, as Alexander (2011: 85) puts it, "necessitate the abolition of private property", DeVore pertinently asks "What is it about 'private property,' more specifically, that might be diminished or abolished?" (DeVore 2017: 647). For those degrowth scholars who advocate for commoning and collective ownership, the focus is clearly on the 'private' aspect of 'private property' (Deriu 2012; Gerber and Gerber 2017; Kallis et al. 2015: 10). However, it is not obvious that collective ownership should necessarily be any more compatible with degrowth than private ownership; as DeVore notes, corporations are collectively owned enterprises (DeVore 2017: 647), and even cooperative enterprises contribute just under five percent of the GDP of the world's ten largest national economies (Sanchez Bajo and Roelants 2011: 105). Instead, the analysis here attributes the growth driver associated with 'private property' not to the fact that it is private, but to the fact that it is 'property': it allows the creation of titles to future resource flows, creating a debt that places pressure on the debtor to meet their repayments. For example, Gerber and Veuthey (2011) examined the replacement of both individual and collective possession by collective property in their study of forest ownership in Cameroon, noting that the creation of property enabled the owners to borrow money at a fixed rate of interest, creating economic pressures to increase productivity. So whilst collective ownership forms such as cooperative housing, state forests, and municipal land may well be less susceptible to drives towards growth (Gerber and Gerber 2017), this is not because they are collectivized but is because their owners are not in debt - and collectives including cooperatives, states, and municipalities do in fact frequently take on debts which they are under pressure to repay (see, for example, Dove 2014; Kirkpatrick 2016; Sanchez Bajo and Roelants 2011). Though a correlation between collective ownership and the prevention of indebtedness may well exist, any such relationship relies on a further explanation of how collectives either avoid or manage indebtedness in ways that individual owners do not. In short, discussions on the relationship between ownership and degrowth might perhaps focus less on whether the owner is a collective or an individual, and a little more on how owners in general avoid or manage debt. In other words, whilst private ownership might very well be compatible with degrowth, it seems that the debt creation characteristic to property is not.

A second point is that since interest-bearing loans may be procured even without collateralization, the incentive to repay is not exclusively due to the desire to avoid loss of collateralized resource stocks. These motivations include the desire to be considered creditworthy in the future and the desire to avoid paying further interest (Allon 2015; Haiven 2014; James 2014; Schuster 2014). The demands imposed upon debtors, which Rolf Steppacher and Pascal van Griethuysen insightfully identify and discuss in terms of solvency, profitability, and time pressure (Steppacher and van Griethuysen 2008; van Griethuysen 2012), might be stronger when defaulters are at risk of dispossession, but nevertheless remain present when debts are unsecured. Though the 
pressures of avoiding dispossession and the processes of accumulation by dispossession are undoubtedly important features of the current economic system (van Griethuysen 2012; Gerber 2014), they are an incomplete picture of diverse ways in which property-related motives drive economic growth. The earlier that a debt is repaid, the less the debtor must pay, and indeed, a debtor's motivation to repay may be particularly acute when interest is compounded, as the exponential growth of compound interest can quickly accumulate into amounts many multiples of the original debt. Again, the implication of this article is that, independently of questions about the ownership of resource stocks, it is the ability of creditors in a property system to create titles to future interest flows that seems incompatible with degrowth.

Third, there remains the central issue of what the institutions of a society without a growing economy might look like (Alexander 2011; Gerber and Gerber 2017; Gerber and Steppacher 2017; Kallis et al. 2015). Fundamental to that issue, I suggest, is the question of which institutions will govern the ownership of resource flows. If transfers under property institutions are motivated by a desire by the creditor to receive a return on their loans, then in a non-growing economy, potential creditors will less reliably expect returns and so have less motivation for transferring resource flows to others. So it may be that a decline in property ${ }^{6}$ will coincide with the emergence of communal ownership institutions in which people give without expectation of return, providing according to their abilities and receiving according to their needs. But this is not the only alternative to property, and may not be the most likely; indeed, across the world and throughout history resource flows have frequently been governed by command ownership institutions where transfers are motivated by deference to status and the threat of direct coercion. Having provided a powerful recent example of the way in which the apparent 'collective' ownership of a stock of land is nevertheless consistent with substantial and coercive accumulation by certain individuals of the resources that flow from that stock (DeVore 2015), DeVore strongly argues that the democratization of resource stock ownership may well play a role in avoiding a coercive postgrowth outcome (DeVore 2017); the analysis presented here suggests that greater attention should also be placed on the institutions that determine who owns the resource flows. In short, for existing models of ownership to provide a better guide to the institutions that may accompany degrowth, a clearer recognition of the distinction between the ownership of stocks and the ownership of flows is required.

\section{Conclusion}

I have argued that existing theories of ownership have long neglected the ownership of resource flows. Ownership of flows, I suggest, cannot be subsumed under a single category of 'private ownership' nor merely divided into 'property' and 'nonproperty' ownership because there are important differences in the way that individuals acquire rights to resource flows: under first possession, flows are retained by the initial possessor; under communal ownership each community member is entitled to acquire flows from others in the group; under command ownership resources flow to those of higher status; and under property ownership flows are transferred to whomever holds a legal title to them. Just as the examination of private, public, common, and club institutions has been instrumental in guiding research into the governance of resource stocks, an important avenue for future research will be to examine how the first possession, communal, command, and property ownership institutions that govern resource flows have been instituted, and in what circumstances they can be maintained.

\section{References}

Alexander, S. 2011. Property beyond growth: toward a politics of voluntary simplicity. Ph.D. dissertation, Melbourne Law School, University of Melbourne.

Allon, F. 2015. Everyday leverage, or leveraging the everyday. Cultural Studies 29: 5-6, 687-706

Ananya, R. 2010. Poverty capital: microfinance and the making of development. London: Routledge.

\footnotetext{
6 For clarity, as throughout the article, my use of the term 'property' here is not synonymous with the term 'ownership'. The term 'property' as used here refers to a specific form of ownership that creates legal titles and thereby enables credit creation; it is therefore quite consistent to write, as I have done here, that the decline of property may well coincide with the rise of other forms of ownership.
} 
Appell, G.N. 1993. Hardin's Myth of the Commons: the tragedy of conceptual confusions. Working Paper 8. Social Transformation and Adaptation Institute.

Binswanger, H.C. 2013. The growth spiral: money, energy, and imagination in the dynamics of the market process. Heidelberg: Springer.

Bromley, D. (ed.). 1992. Making the commons work: theory, practice, and policy. San Francisco: ICS Press.

Blackstone, W. 1765-1769. Commentaries on the laws of England. 4 vols. New Haven, CT: The Avalon Project at Yale Law School.

Calvo-Mendieta, I., O. Petit and F.-D. Vivien. 2017. Common patrimony: a concept to analyze collective natural resource management. The case of water management in France. Ecological Economics 137: 126-132.

Ciriacy-Wantrup, S.V. and R.C. Bishop. 1975. 'Common property' as a concept in natural resources policy. Natural Resources Journal 15(4): 713-727.

Coase, R.H. 1960. The problem of social cost. Journal of Law and Economics 3(1): 1-44.

Cole, D.H. and E. Ostrom. 2012. The variety of property systems and rights in natural resources. In Cole D.H. and E. Ostrom (eds.) Property in Land and Other Resources. Cambridge, MA: Lincoln Institute of Land Policy. Pp. 37-66.

Daly, H.E. and J. Farley. 2011. Ecological economics: principles and applications. 2nd ed. Washington, DC: Island Press.

Deriu, M. 2012. Democracies with a future: degrowth and the democratic tradition. Futures 44(6): 553-561.

DeVore, J. 2015. The landless invading the landless: participation, coercion, and agrarian social movements in the Cacao lands of Southern Bahia, Brazil. The Journal of Peasant Studies 42(6): 1201-1223.

DeVore, J. 2017. Trees and springs as social property: a perspective on degrowth and redistributive democracy from a Brazilian squatter community. Journal of Political Ecology 24: 644-666.

Dove, J.A. 2014. Financial markets, fiscal constraints, and municipal debt: lessons and evidence from the Panic of 1873. Journal of Institutional Economics 10 (01): 71-106.

Ellickson, R.C. 1991. Order without law. Cambridge, MA: Harvard University Press.

Ellickson, R.C. 1993. Property in land. Yale Law Journal 102(6): 1315-1400.

Farley, J. 2012. The economics of sustainability. In Cabezas, H. and U. Diwekar (eds.) Sustainability: multidisciplinary perspectives. Sharjah: Bentham Science. Pp. 40-60.

Feeny, D., F. Berkes, B.J. McCay and J.M. Acheson. 1990. The tragedy of the commons: twenty-two years later. Human Ecology 18(1): 1-19.

Garfinkle, S.J. 2004. Shepherds, merchants, and credit: some observations on lending practices in Ur III Mesopotamia. Journal of the Economic and Social History of the Orient 47(1): 1-30.

Georgescu-Roegen, N. 1965. The institutional aspects of peasant communities: an analytical view. In Georgescu-Roegen, N. Energy and economic myths. New York, NY: Pergamon Press. Pp. 199-234.

Georgescu-Roegen, N. 1971. The entropy law and the economic process. Cambridge, MA: Harvard University Press.

Gerber, J.-F. 2014. The role of rural indebtedness in the evolution of capitalism. Journal of Peasant Studies 41(5): 729-747.

Gerber, J.-F. 2015. An overview of local credit systems and their implications for post-growth. Sustainability Science 10(3): 413-423.

Gerber, J.-D. and J.-F. Gerber. 2017. Decommodification as a foundation for ecological economics. Ecological Economics 31: 551-556.

Gerber, J.-F. and A. Scheidel. 2018. In search of substantive economics: comparing today's two major sociometabolic approaches to the economy - MEFA and MuSIASEM. Ecological Economics 144: 186-194.

Gerber, J.-F. and R. Steppacher. 2017. Basic principles of possession-based economies. Anthropological Theory 17(2): 217-238. 
Gerber, J.-F. and S. Veuthey. 2011. Possession versus property in a tree plantation: socioenvironmental conflict in Southern Cameroon. Society and Natural Resources 24: 831-848.

Giampietro, M., K. Mayumi and J. Ramos-Martin. 2009. Multi-scale integrated analysis of societal and ecosystem metabolism (MuSIASEM): theoretical concepts and basic rationale. Energy 34(3): 313-322.

Graeber, D. 2011. Debt: the first 5000 years. Brooklyn, NY: Melville House Printing.

Haberl, H. 2015. Competition for land: a sociometabolic perspective. Ecological Economics 119: 424-431.

Haiven, M. 2014. Cultures of financialization: fictitious capital in popular culture and everyday life. Basingstoke: Palgrave-MacMillan.

Hardin, G. 1968. The tragedy of the commons. Science 162(3859): 1243-1248.

Hardin, G. 1991. The tragedy of the unmanaged commons: population and the disguises of providence. In Andelson, R.V. (ed.). Commons without tragedy: protecting the environment from overpopulation - a new approach. London: Shepheard-Walwyn. Pp. 162-85.

Heinsohn, G. 2008. Where does the market come from? In Steiger, O. (ed.) Property economics: property rights, creditor's money and the foundations of the economy. Marburg: Metropolis. Pp. 243-261.

Heinsohn, G. and O. Steiger. 2000. The property theory of interest and money. In Smithin, J. (ed.). What is money? London: Routledge. Pp. 67-100.

Heinsohn, G. and O. Steiger. 2008. Collateral and own capital: the missing links in the theory of the rate of interest and money. In Steiger (ed.) Property economics. Marburg: Metropolis. Pp. 181-222.

Heinsohn, G. and O. Steiger. 2013. Ownership economics. Ed. and trans. by F. Decker. London: Routledge.

Hoffmann, S. 2013. Property, possession and natural resource management: towards a conceptual clarification. Journal of Institutional Economics 9(1): 39-60.

Hohfeld, W.N. 1913. Some fundamental legal conceptions as applied in judicial reasoning. Yale Law Journal 23(1): 16-59.

Hohfeld, W.N. 1917. Fundamental legal conceptions as applied in judicial reasoning. Yale Law Journal 26(8): $710-770$.

Honoré, A.M. 1961. Ownership. In Guest, A.G. (ed.). Oxford essays in jurisprudence. Oxford: Clarendon Press. Pp. 107-147.

Hoskins, W.G. and L.D. Stamp. 1963. The common lands of England and Wales. London: Collins.

Hudson, M. 2000. How interest rates were set, 2500 BC-1000 AD: mas, tokos and foenus as metaphors for interest accruals. Journal of the Economic and Social History of the Orient 43(2): 132-161.

Hudson, M. 2002. Reconstructing the origins of interest-bearing debt. In Hudson, M. and M. Van de Mieroop (eds.). Debt and economic renewal in the ancient Near East. Bathesda, MD: Capital Decisions Limited. Pp. 7-58.

James, D. 2014. Money from nothing: indebtedness and aspiration in South Africa. Stanford, CA: Stanford University Press.

Kallis, G., F. Demaria and G. D'Alisa (eds.). 2015. Degrowth: a vocabulary for a new era. London: Routledge.

Kanngiesser, P., F. Rossano and M. Tomasello. 2015. Late emergence of the first possession heuristic: evidence from a small-scale culture. Child Development 86(4): 1282-1289.

Katz, L. 2008. Exclusion and exclusivity in property law. University of Toronto Law Journal 58(3): 275-315.

Kirkpatrick, L.O. 2016. The new urban fiscal crisis: finance, democracy, and municipal debt. Politics and Society 44(1): 45-80.

Klein, D.B. and J. Robinson. 2011. Property: a bundle of rights? Prologue to the Property Symposium. Econ Journal Watch 8(3): 193-204.

Lau, J.Y. and J. Smithin. 2002. The role of money in capitalism. International Journal of Political Economy 32(3): 5-22.

Lazzarato, M. 2012. The making of the indebted man: an essay on the neoliberal condition. Los Angeles, CA: Semiotext(e). 
Libecap, G.D. 2007. Assigning property rights in the common pool: implications of the prevalence of firstpossession rules for ITQs in fisheries. Marine Resource Economics 22(4): 407-423.

Lueck, D. 1995. The rule of first possession and the design of the law. Journal of Law and Economics 38(2): 393-436.

Lueck, D. 1998. First possession. In Newman, P. (ed.) The new Palgrave dictionary of economics and the law Basingstoke: Palgrave-MacMillan. Pp. 5202-5208.

Maurer, B. 1999. Forget Locke? From proprietor to risk bearer in new logics of finance. Public Culture 11(2): 365-385.

McGinnis, M.D. 2011. An introduction to IAD and the language of the Ostrom Workshop: a simple guide to a complex framework. Policy Studies Journal 39(1): 169-183.

McKean, M.A. 2000. Common property: what is it, what it is good for, and what makes it work? In Gibson, C. C., M.A. McKean and E. Ostrom. People and forests: communities, institutions, and governance. Cambridge, MA: MIT Press. Pp. 27-55.

Meyer, J.M. 2009. The concept of private property and the limits of the environmental imagination. Political Theory 37(1): 99-127.

M'Gonigle, R.M. 1999. Ecological economics and political ecology: towards a necessary synthesis. Ecological Economics 28(1): 11-26.

Munro, J.H. 2003. The medieval origins of the financial revolution: usury, rentes, and negotiability. International History Review 25(3): 505-562.

Noonan, J.T. 1957. The scholastic analysis of usury. Cambridge, MA: Harvard University Press.

Ostrom, E. 1990. Governing the commons: the evolution of institutions for collective action. Cambridge: Cambridge University Press.

Ostrom, E. 2005. Understanding institutional diversity. Princeton, NJ: Princeton University Press.

Ostrom, E. 2011. Background on the institutional analysis and development framework. Policy Studies Journal 39(1): 7-27.

Penner, J.E. 1997. The idea of property in law. Oxford: Oxford University Press.

Pipes, R. 1999. Property and freedom: the story of how through the centuries private ownership has promoted liberty and the rule of law. New York, NY: Alfred Knopf.

Ribot, J.C. and N.L. Peluso. 2003. A theory of access. Rural Sociology 68(2): 153-181.

Rose, C.M. 1985. Possession as the origin of property. University of Chicago Law Review 52(1): 73-88.

Rose, C.M. 1994. Property and persuasion: essays on the history, theory, and rhetoric of ownership. Boulder, CO: Westview.

Rose, C.M. 1998. Canons of property talk, or, Blackstone's anxiety. Yale Law Journal 108(3): 601-632.

Ross, A. 2014. Creditocracy and the case for debt refusal. New York, NY and London, England: OR Books.

Samuelson, P.A. 1954. The pure theory of public expenditure. Review of Economics and Statistics 36: 387389.

Sanchez Bajo, C. and B. Roelants. 2011. Capital and the debt trap: learning from cooperatives in the Global Crisis. New York, NY: Springer.

Schuster, C. 2014. The social unit of debt: gender and creditworthiness in Paraguayan microfinance. American Ethnologist 41(3): 563-578.

Singer, J.W. 2008. Entitlement: the paradoxes of property. New Haven, CT: Yale University Press.

Steiger, O. 2006. Property Economics versus New Institutional Economics: alternative foundations of how to trigger economic development. Journal of Economic Issues 40(1): 183-208.

Steppacher, R. and P. van Griethuysen. 2008. The differences between biotic and mineral resources and their implications for the conservation-climate debate. Policy Matters 16: 30-37.

Storck, T. 2009. Is usury still a sin? Communio: International Catholic Review 36(3): 447-474. 
Strunz, S., B. Bartkowski and H. Schindler. 2015. Is there a monetary growth imperative? UFZ Discussion Papers 5/2015.

Strunz, S., B. Bartkowski and H. Schindler. 2017. Is there a monetary growth imperative? In Victor, P. and B. Dolter (eds.). Handbook on growth and sustainability. Cheltenham: Edward Elgar. Pp. 326-355.

Temper, L. 2016. Who gets the HANPP (Human Appropriation of Net Primary Production)? Biomass distribution and the bio-economy in the Tana Delta, Kenya. Journal of Political Ecology 23(1): 410433.

Underkuffler, L.S. 2003. The idea of property: its meaning and power. Oxford, England: Oxford University Press.

Van Griethuysen, P. 2012. Bona diagnosis, bona curatio: how property economics clarifies the degrowth debate. Ecological Economics 84: 262-269. 